ACTA THERIOLOGICA

Vol. 27, 15: 191-212, 1982

\title{
Dung Properties and Defecation Characteristics in Some Scottish Herbivores, with an Evaluation of the Dung-volume Method of Assessing Occupance
}

\author{
David WELCH
}

\begin{abstract}
Welch D., 1982: Dung properties and defecation characteristics in some Scottish herbivores, with an evaluation of the dung-volume method of assessing occupance. Acta theriol., 27, 15: 191-212 [With 8 Tables \& 3 Figs.]

The inter-relationships of dry weight, fresh weight and volume were studied with dung of cattle, sheep, red deer (Cervus elaphus), hares (Lepus spp.), rabbits (Oryctolagus cuniculus) and red grouse (Lagopus lagopus). Dry weight to volume ratios were dependent on the initial dry-matter content, but also affected by weather, with shrinkage on drying-out. Cattle dung was clearly distinct in having a high moisture content. Volumes and weights of individual pellets were measured, and the number of pellets per defecation counted. From these data and other published information it is calculated that dung output for animals of average size ranges from $6 \mathrm{ml} / \mathrm{hr}$ in red grouse to $60 \mathrm{ml} / \mathrm{hr}$ in sheep to $800 \mathrm{ml} / \mathrm{hr}$ in cattle. Tests on the use of the dung-volume method to assess herbivore occupance are described.

[Institute of Terrestrial Ecology, Hill of Brathens, Banchory, Kincardineshire, AB3 4BY, Great Britain]
\end{abstract}

\section{INTRODUCTION}

Direct measurement of the occupance of ground by large mammalian herbivores poses many difficulties, stemming from their complex behaviour patterns and herding tendency. There are also problems in making observations at night, in bad weather, and in remote situations. Hence indirect methods of assessing occupance have been widely used, especially measurements of dung. For deer many workers have counted pellet groups in relation to area, as reviewed by Neff (1968); for lagomorphs pellet numbers have been counted. But these counts also have disadvantages e.g. the regularity of defecation may vary, and when usage is heavy individual pellet groups are difficult to separate.

Measuring the quantity of dung deposited in unit time and area avoids many of the drawbacks of the counting methods. Because determination of dry weight is time-consuming, and there are problems with fluid dung in handling and avoiding contamination from soil and debris, the alternative of using volume was examined.

The dung-volume method was initially developed to assess sheep 
distribution (Rawes \& Welch 1966). Fived plots are first cleared of all dung, then collections are made at sufficient frequency as to ensure that no significant amounts of dung are lost or consumed by beetles, earthworms or other fauna. Three-week intervals have been used in northeast Scotland (Welch, in prep.); with dry fibrous dung as in grouse (Lagopus lagopus) and hares (Lepus spp.) periods can be longer, but with an active dung fauna under warm and wet conditions they must be shorter. Plot size and number depend on herbivore type and density, spatial variability in amounts of dung being less in small animals and ones that defecate more frequently. In the above-mentioned study with species ranging in size from grouse to cattle, there were eight plots per site, each of $15 \mathrm{~m}^{2}$ and having long narrow shape to prevent dung being overlooked (van Etten \& Bennett 1965). Volumes of dung are usually determined by displacement of water in 1 or 2-litre polythene cylinders. For very dry dung, which can rapidly absorb moisture, volume is better estimated without water, from the column occupied less $40 \%$ for the air space between pellets. This value can be calculated and is also apparent from the displacement normally obtained by completely filling the water column with pellets. Cow pats are often quartered to reduce bulk, or their volumes estimated from measures of depth and diameter.

This paper presents data defining the relationships between volume and the other dung parameters, and describes tests of the dung-volume method against direct assessment of occupance at eight moorland sites and one sown grassland. Lastly conversion factors to relate volume deposition rates to animal densities are calculated, making use of other published data.

\section{METHODS}

\section{Dung Volume - Dry Weight - Fresh Weight Inter-relationships}

Dung up to three weeks old was obtained from sites in north-east Scotland. Sampling took place on 50 days between 1969 and 1977, in each of three periods (spring-summer=May-August; autumn=September-December; winter $=$ JanuaryApril), and in dry weather (no appreciable rainfall in previous week and bare soil dusty), average weather and wet weather (substantial rainfall prior to and during sampling). Half of each sample was used for dry-weight and half for volume determination, both halves being first weighed fresh. Variation in the dry weight: volume ratio $(D W: V)$ in relation to season, weather and also dung density, was analysed by the method of fitting constants, using the triple groupings specified above, and for density arbitrarily classifying samples into light dung (frest weight: volume ratio $(F W: V)<0.83$ ), medium dung (ratio $>0.83<0.91$ ), and heavy dung. 
Sample size averaged $60 \mathrm{ml}$ for grouse, hares and rabbits (Oryctolagus cuniculus), $120 \mathrm{ml}$ for sheep, $200 \mathrm{ml}$ for deer (Cervus elaphus) and about $1,000 \mathrm{ml}$ for cattle. Thus the samples often consisted of only part of a defecation in cattle, of two or three pellet groups in deer and sheep, and of many depositions in lagomorphs and grouse. This obscured variation between individuals and individual depositions, but approximated to the material normally sampled in the dungvolume method. The sheep were all of the Scottish Blackface breed; the cattle were mainly Aberdeen-Angus and Herefords, sometimes suckler cows and their followers, sometimes heifers or steers.

\section{Pellet Volume, Weight and Number-per-group Determination}

Mean sizes and weights were calculated from the number of pellets in the samples used to measure dry weight and volume. Pellets were counted in 300 deer and 300 sheep groups from several moorland sites, and the volume of 20 pellets in each was obtained. Pellet groups were defined as the depositions from single defecations; they were distinguished by the appearance and proximity of the droppings, indistinct groups being ignored.

\section{Testing the Dung-volume Method by Direct Observation of Occupance}

Census areas of $0.2-1.1$ ha were set up at seven moorland sites where dungvolume estimates of occupance by free-ranging herbivores were being obtained. Counting took place from a distance approximately once a day at any time during daylight. Night counts were made with the aid of a search-light at two of the sites used by red deer. At another site with grouse, hares and rabbits the chief herbivores, each count included a traverse to avoid sitting animals being missed, and dung was collected seven times each year from plots totalling $205 \mathrm{~m}^{2}$. Additionally a sown grassland utilised by cattle was monitored with a time-lapse camera, photographs of a 0.25 ha census area being taken every 30 minutes. Visits early and late each day enabled new depositions to be identified and marked for subsequent measurement.

\section{Observations of Variability in Dung Output}

Four hinds and four ewes, each weighing about $60 \mathrm{~kg}$ and fitted with faecal harnesses, were under study at the Rowett Research Station, Aberdeen, and the data have been made available by $\mathrm{Dr}$ R. N. B. Kay. Each trial began with a period of acclimatisation, then dung was collected at 2-hr intervals for two days, at $3-\mathrm{hr}$ intervals for one day, and at intervals of up to 24 hours for the next seven days. The dung was weighed fresh. Throughout the trials food (grass, hay and heather) was given at 7.45 and $15.30 \mathrm{hrs}$ G. M. T.

\section{RESULTS WITH DISCUSSION}

\section{Dung Volume - Dry Weight - Fresh Weight Inter-relationships}

Mean $D W: V$ ratios were similar in all animals but cattle (Table 1), and much less variable than the dry weight to fresh weight ratio $(D W$ : 
Table 1

Mean dry-matter content $(D W: F W, g / g)$ and dry weight to volume ratio $(D W: V$, $\mathrm{g} / \mathrm{ml}$ ) in dung of six herbivores, with $95 \%$ confidence limits, and the relation of variation in $D W: V$ to season $(S)$, weather $(W)$ and dung density $(D)$.

\begin{tabular}{lcccccc}
\hline & \multicolumn{2}{c}{$\begin{array}{c}\text { No. of } \\
\text { samples }\end{array}$} & $D W: F W$ & $D W: V$ & $\begin{array}{c}\text { Variance in } D W: V \\
\text { ratio accounted for by } \\
S\end{array}$ \\
\hline Sheep & 153 & $.36 \pm .03$ & $.27 \pm .01$ & 8 & 29 & 26 \\
Red Deer & 58 & $.28 \pm .02$ & $.25 \pm .01$ & $\mathrm{x}$ & $\mathrm{x}$ & $\mathrm{x}$ \\
Cattle & 108 & $.16 \pm .01$ & $.16 \pm .01$ & 3 & 10 & 19 \\
Hare & 92 & $.38 \pm .05$ & $.25 \pm .01$ & 3 & 64 & 57 \\
Rabbit & 68 & $.35 \pm .06$ & $.24 \pm .02$ & 9 & 49 & 33 \\
Red Grouse & 86 & $.36 \pm .05$ & $.26 \pm .01$ & 1 & 25 & 27 \\
\hline
\end{tabular}

$\mathrm{x}=$ analysis impossible due to groupings being unrepresented

$F W)$. Fresh weight is affected by weather prior to sampling, but in cattle crust formation minimises evaporation, and the $D W: V$ and $D W: F W$ ratios were equally low. Thus the average density $(F W: V)$ of cattle dung was 1.0, and no samples belonged to the light dung class; in contrast rabbit and hare pellets can rapidly lose water and many samples

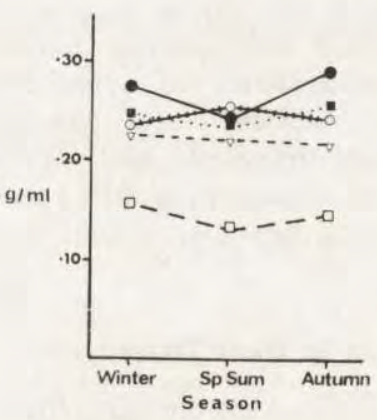

$\longrightarrow$ Sheep

Rabbit

D- Cattle

Red Grouse
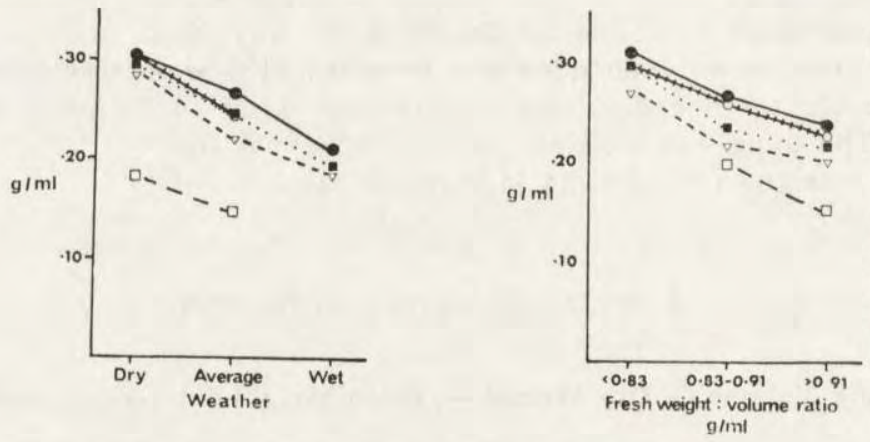

Fig. 1. Dung dry weight: volume ratios in different seasons for average weather, and year-round averages in different weathers and for different densities. 
were classified as light. The density of newly deposited dung was usually close to unity but varied somewhat seasonally.

Variation in the $D W: V$ ratio was related to weather and dung density, suggesting that drying-out leads to shrinkage, and only little related to season (Table 1, Fig. 1). Although in summer a fall in dry-matter content could be expected due to higher forage digestibility, and ruminant dung was more fluid on deposition, $D W: V$ ratios were only slightly reduced probably because evaporation increased. Indeed in grouse which feed largely on heather throughout the year, the ratio rose. In cattle little of the variation in the $D W: V$ ratio could be accounted for by any of the three factors, values being very dependent on initial dry-matter contents.

All the dung examined including cattle conformed to the same relationships (Fig. 2). Below a dry-matter content of $18 \%$ dung is semi-liquid and volume measures solely the amount of water produced, hence dry weight falls without affecting $F W: V$. Above $18 \%$ the solid particles become bound more closely together, and the volume is increasingly dependent on the amount of dry matter; the increase in $D W: V$ is
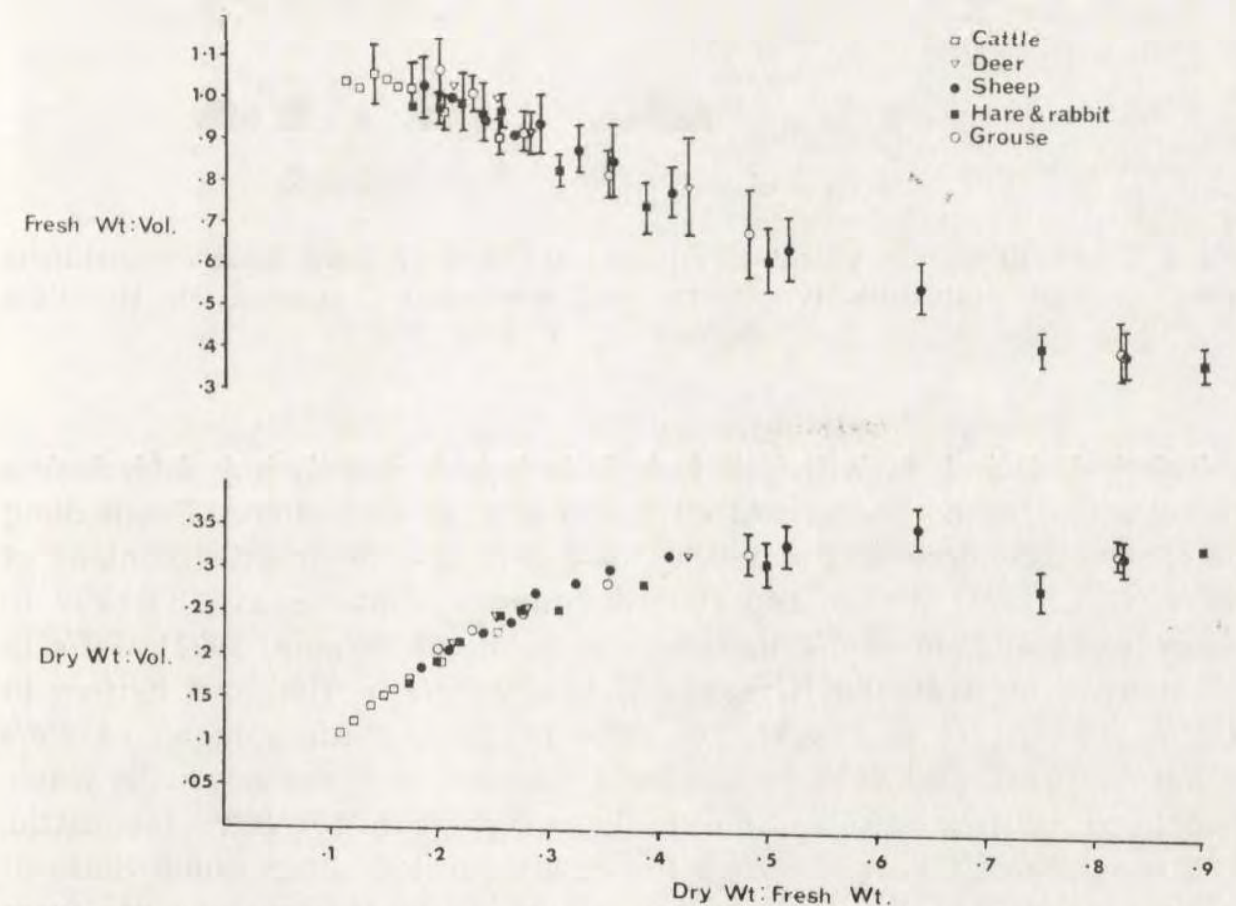

Fig. 2. The relationship between dung dry weight-to-volume and fresh weight-tovolume ratios and dry-matter content. Mean values are given for groups of 10-20 samples in sequence of dry-matter content; confidence limits are shown where greater than 0.03 . 
partly due to shrinkage. Above $35 \%$ the $D W: V$ ratio seems constant indicating little or no shrinkage, but the $F W: V$ ratio falls due to dryingout. The scatter of points in Fig. 2 reflects differences in the nature and fibrosity of dung besides inaccuracies in measurements; several samples of grouse dung had anomalously high dry weight probably due to containing grit.

The occurrence of shrinkage was confirmed in a small trial in which aliquots of fresh sheep dung were collected at intervals over a 20-day period. Shrinkage was associated with reductions in fresh weight, and took place during dry weather (Fig. 3); subsequent wet weather was inconsistent in effect.

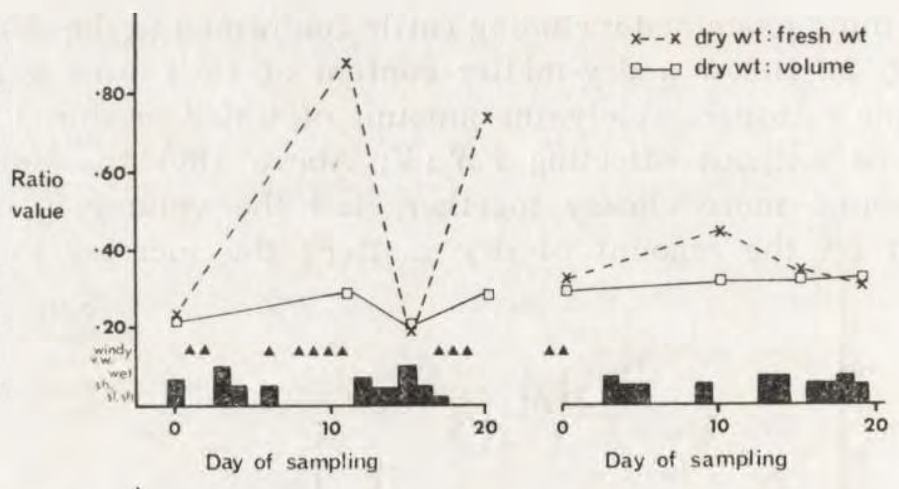

Fig. 3. Trends in the dry weight-to-volume ratio of sheep dung. Weather conditions were assessed arbitrarily ( $\mathrm{vw}=$ wery wet, $\mathrm{w}=$ wet, $\mathrm{sh}=$ showers, $\mathrm{sl}$. $\mathrm{sh}=$ slight showers, $\triangle=$ windy).

These results agree with previous findings, but hardly any information is available for non-domesticated herbivores, or on volume. Fresh dung of captive red deer had a density of 1.06 and a dry-matter content of $30 \%$ (Gill, 1961). Other reported dry-matter contents are $8-13 \%$ in dairy cows and $40-50 \%$ in sheep in Scotland (Frame, 1971), 14\% in beef cattle in Australia (Greenham, 1972), 15\% in Hereford heifers in U.S.A. (Weeth et al., 1967), $30-50 \%$ in sheep with a mean of $35 \%$ (Church, 1972), and 45\% in Border Leicesters and Merinos with water restricted (Wilson, 1970). Church, however, gave $15-30 \%$ for cattle, and Olechowicz (1974) $12-29 \%$ for newly-egested sheep dung. State of health affects the dung, diarrhoea reducing dry-matter contents from $20 \%$ to $9 \%$ in calves (Blaxter \& Wood, 1953), whilst Greenham (1972) related variation of similar magnitude in freshly-deposited dung to pasture type and season. Rook \& Balch (1959) ascribed the fluid consist- 
ency of cattle dung in spring to greater herbage digestibility reducing dry-matter output, mature plant structural components being virtually absent. In these circumstances, as when dung contains grit, volume better reflects animal occupance than dry weight. However, the variation in the $D W: V$ ratio due to weather precludes exact estimation of occupance; in very wet weather or drought volumes may be $20 \%$ above or below average-weather values.

\section{Pellet Volume, Weight and Numbers per Group}

Single pellets of sheep, grouse and hares were roughly $1 \mathrm{ml}$ in volume (Table 2). Mountain hare (Lepus timidus) pellets were markedly larger

Table 2

Mean dry weights and volumes of dung pellets in six herbivores, and the range of mean values determined on different occasions.

\begin{tabular}{lccc}
\hline & Dry weight, $\mathrm{g}$ & Volume, $\mathrm{ml}$ & Range of volumes, ml \\
\hline Sheep & .28 & 1.07 & $.61-1.61$ \\
Red Deer & .42 & 1.80 & $1.45-2.10$ \\
Red Grouse & .29 & 1.07 & $.80-1.26$ \\
Rabbit & .08 & .37 & $.29-.74$ \\
Brown Hare & .17 & .70 & $.38-.98$ \\
Mountain Hare & .24 & .89 & $.69-1.11$ \\
\hline
\end{tabular}

Table 3

Mean numbers of dung pellets per group, and estimated volumes of pellet groups, with $95 \%$ confidence limits.

\begin{tabular}{lcc}
\hline & $\begin{array}{c}\text { Number of pellets } \\
\text { per group }\end{array}$ & $\begin{array}{c}\text { Estimated volume of } \\
\text { single pellet groups, ml }\end{array}$ \\
\hline Sheep & $75 \pm 4$ & $60 \pm 4$ \\
Red Deer & $86 \pm 4$ & $127 \pm 6$ \\
\hline
\end{tabular}

than brown hare (Lepus europaeus), surprisingly since the former is the smaller animal; no other differences in dung were found between these species. Variation in pellet size and weight was quite large, even though no means were based entirely on dung of very young animals.

The groups of sheep and red deer contained similar numbers of pellets, but mean volume for sheep was less than half that of deer due to the smaller size of individual pellets (Table 3). Number of pellets per group ranged from 25 to 228 in sheep, and from 21 to 178 in deer. There was no consistent relationship between pellet size and number per group in either animal. 
Values obtained by other workers are similar: red deer in a zoo produced depositions containing on average 78 pellets, with weight $58 \mathrm{~g}$ (Riney, 1957), and de Bie (1976) observing four sheep on a rough grazing for a total of 56 hours found the defecations to vary between 3 and $270 \mathrm{ml}$ in volume, the average being $67 \mathrm{ml}$. The air-dry weights of pellets of mature jackrabbits (Lepus californicus and L. alleni) eating native forage were 0.18 and $0.22 \mathrm{~g}$ (Arnold \& Reynolds, 1943). Mean values were influenced by diet, but not age, size or weight of the animals; pellet size increased when intake rose, but defecation rate changed little. Also with L. californicus, Hansen (1972) found a mean dry weight of $0.12 \mathrm{~g}$, and a winter maximum of $0.16 \mathrm{~g}$ when only adults were present.

Pellet-group volume and the daily output of dung are related by the daily defecation rate, which has often been estimated in order to convert pellet-group counts into animal densities. From the data in Tables 2 and 3 , and the overall estimates of dung output in Tables 4 and 5 , it can be calculated that 17 defecations per day occur in sheep and 13 in deer. Other estimates of daily defecation rate are, for sheep, 13-16 (Longhurst, 1954) and 18 (de Bie, 1976), and, for red deer or elk, 10 (Riney, 1957), 11 and 12.5 (Neff, 1968). Neff thought that good-quality or high-moisture content food, high intake rates, abrupt changes of diet to more-digestible food, or the animals being young, ccuid cause more frequent defecation, but the reaction of group size has not been estabiıshed. In lagomorphs, however, low defecation rate is perhaps associated with greater pellet size on some diets (Cochran \& Stains, 1961). In rabbits defecation rates have been estimated as 746 pellets/day in New Zealand (Taylor \& Williams, 1956), and 376/day in January and 4.46/day in April in Wales (Lockley, 1962), and in hares as $200-450$ pellets/day in Finland (Lampio, 1952), 208 in Scotland (Flux, 1970) and 410 in New Zealand (Flux, 1967).

\section{Testing the Dung-volume Method by Direct Observation of Occupance}

The volumes of dung deposited within individual sampling periods at the five moorland sites did not conform closely to the estimated densities of cattle and sheep (Table 4). But the dung totals, based on eight pluts per site, were much less variable than the densities, there being many observations when animals were absent. At both Midtown sites large amounts of sheep dung were deposited in three-week periods in November 1970 and 1971 ; during these periods at Midtown AgF no sheep were seen in 16 counts in 1970, whilst in 197145 sheep were recorded, 38 being 
present on the 0.21 ha site on one count. Thus with intermittent visits from sheep grazing in a tight herd very frequent counts are needed to obtain a reliable average. However, the overall rates of dung deposition obtained, $57 \mathrm{ml}$ per sheep-hour and $1254 \mathrm{ml}$ per cattle-hour, are reasonably similar to estimates made in other ways (Table 8 ).

Table 4

Comparison between volumes of dung deposited and densities of sheep and cattle estimated by counting. Period 1=June 1969-May 1970, 2=June 1970-May 1971, 3=June 1971-May 1972, 4=June 1972-September 1972.

\begin{tabular}{|c|c|c|c|c|c|c|c|c|}
\hline \multirow[t]{2}{*}{ Site } & \multirow[t]{2}{*}{ Period } & \multirow{2}{*}{$\begin{array}{l}\text { Number } \\
\text { of } \\
\text { counts }\end{array}$} & \multicolumn{2}{|c|}{$\begin{array}{c}\text { Estimated } \\
\text { density } \\
\text { (animals/ha) } \\
\end{array}$} & \multicolumn{2}{|c|}{$\begin{array}{l}\text { Dung deposited } \\
\qquad\left(\mathrm{ml} / \mathrm{m}^{2}\right)\end{array}$} & \multicolumn{2}{|c|}{$\begin{array}{l}\text { Calculated rate of } \\
\text { dung deposition } \\
\text { (ml/animal-hr) }\end{array}$} \\
\hline & & & Sheep & Cattle & Sheep & Cattle & Sheep & Cattle \\
\hline \multirow[t]{5}{*}{ Part II } & 1 & 223 & $0.95^{1}$ & $0.02^{2}$ & 31 & $57^{1}$ & 36 & 3631 \\
\hline & 2 & 282 & $0.84^{1}$ & $0.03^{2}$ & 38 & $138^{1}$ & 66 & 5435 \\
\hline & 3 & 233 & $0.88^{1}$ & $0.04^{2}$ & 38 & $153^{1}$ & 49 & 4161 \\
\hline & 4 & 138 & 0.90 & 0 & 7 & $80^{1}$ & 28 & $\infty$ \\
\hline & Ail & 876 & 0.89 & $0.02^{1}$ & 114 & 428 & 43 & 5856 \\
\hline \multirow[t]{5}{*}{ Part III } & 1 & 224 & $0.53^{2}$ & $0.14^{1}$ & $17^{1}$ & $115^{1}$ & 36 & 937 \\
\hline & 2 & 283 & $0.43^{2}$ & $0.54^{1}$ & 25 & $83^{1}$ & 65 & 171 \\
\hline & 3 & 233 & $0.28^{2}$ & $0.14^{2}$ & 18 & 130 & 73 & 1055 \\
\hline & 4 & 134 & $0.93^{1}$ & $0.09^{2}$ & $2^{1}$ & 0 & 8 & 0 \\
\hline & All & 874 & 0.49 & 0.26 & 61 & 328 & 42 & 428 \\
\hline \multirow[t]{4}{*}{ Knock } & 2 & 310 & $0.07^{2}$ & $0.08^{2}$ & 13 & 489 & 215 & 6444 \\
\hline & 3 & 224 & $0.43^{2}$ & $0.45^{2}$ & $3^{1}$ & 375 & 9 & 961 \\
\hline & 4 & 132 & $1.00^{1}$ & 0 & $2^{1}$ & $46^{1}$ & 5 & $\infty$ \\
\hline & All & 666 & $0.37^{1}$ & $0.19^{2}$ & 18 & 910. & 24 & 2296 \\
\hline \multirow{4}{*}{$\begin{array}{l}\text { Midtown } \\
\text { AgF }\end{array}$} & & & & & & & & \\
\hline & $\begin{array}{l}2 \\
3\end{array}$ & $\begin{array}{l}315 \\
225\end{array}$ & $\begin{array}{l}0.03^{2} \\
1.61^{2}\end{array}$ & $0.02^{2}$ & $\begin{array}{r}100 \\
41\end{array}$ & 246 & $\begin{array}{r}319 \\
28\end{array}$ & $\begin{array}{c}\infty \\
13268\end{array}$ \\
\hline & 4 & 133 & 0 & $2.36^{1}$ & +2 & 617 & $\infty$ & 870 \\
\hline & All & 673 & $0.55^{2}$ & $0.47^{1}$ & 147 & 1086 & 124 & 1074 \\
\hline \multirow{4}{*}{$\begin{array}{l}\text { Midtown } \\
\text { Ns }\end{array}$} & & & & & & $93^{1}$ & & \\
\hline & $\begin{array}{l}2 \\
3\end{array}$ & $\begin{array}{l}315 \\
225\end{array}$ & $\begin{array}{l}0.63^{2} \\
1.69^{1}\end{array}$ & $0.20^{2}$ & 34 & $118^{1}$ & $\begin{array}{r}123 \\
23\end{array}$ & $\begin{array}{r}62.00 \\
661\end{array}$ \\
\hline & 4 & 133 & $0.05^{2}$ & $0.42^{1}$ & $\begin{array}{l}+2 \\
+2\end{array}$ & $290^{1}$ & 16 & 2340 \\
\hline & All & 673 & $0.87^{1}$ & $0.17^{1}$ & 106 & $501^{1}$ & 58 & 1441 \\
\hline All Sites & All & & & & & & 57 & 1254 \\
\hline
\end{tabular}

1 Standard error exceeds $25 \%$ of mean, ${ }^{2}$ Standard error exceeds $50 \%$ of mean, $+=$ trace,

For deer also, the counts were more variable than the dung data (Table 5). At Feshie A (0.58 ha) no deer were present in 425 of 460 counts, but on two occasions 74 and 77 deer were recorded, being $19 \%$ of the total observed. Much less dung was deposited than at Feshie B, yet more animals were seen, so the calculated rates of dung deposition are widely divergent. The pattern was consistent for individual sampling periods during the six winter months when most occupance occurred 3- Acia Theriologica 
(Welch, 1971). No counts were made between midnight and 9 a.m., and the presence of deer on Feshie A mainly around dusk and on Feshie B later in the night suggests that this led to the estimated density being exaggerated on A and underestimated on B. There was less variation in the estimated densities of grouse, hares and rabbits (Table 5), the

Table 5

Comparison between volumes of dung deposited and densities of red deer, red grouse, hares and rabbits estimated by counting, with $95 \%$ confidence limits.

\begin{tabular}{|c|c|c|c|c|c|}
\hline Animal & Site & $\begin{array}{c}\text { Number } \\
\text { of } \\
\text { counts }\end{array}$ & $\begin{array}{c}\text { Estimated } \\
\text { density } \\
\text { (animals/ha) }\end{array}$ & $\begin{array}{l}\text { Dung deposited } \\
\qquad\left(\mathrm{ml} / \mathrm{m}^{2}\right)\end{array}$ & $\begin{array}{c}\text { Calculated rate } \\
\text { of deposition } \\
\text { (ml/animal-hr) }\end{array}$ \\
\hline \multirow[t]{3}{*}{ Red Deer } & Feshie A & 460 & $2.93 \pm 1.34$ & $54 \pm 14$ & 21 \\
\hline & Feshie B & 460 & $0.96 \pm 0.56$ & $113 \pm 38$ & 135 \\
\hline & Combined & & 2.31 & 84 & 83 \\
\hline Red Grouse & Part I & 500 & $0.34 \pm 0.12$ & $5 \pm 2$ & 6 \\
\hline $\begin{array}{l}\text { Hares and } \\
\text { Rabbits }\end{array}$ & Part I & 500 & $0.16 \pm 0.05$ & $15 \pm 2$ & 35 \\
\hline
\end{tabular}

The period of study was from May 1969 to May 1970 at Feshie $A$ and $B$, and from May 1967 to May 1970 at Part I.

lagomorphs normally being recorded singly on the 0.4 ha site. Calculated rates of dung deposition were consistent between years in grouse, but fell for hares and rabbits, due partly to a decline in the proportion of occupance contributed by hares.

Lack of night-time observations could cause estimated densities to be nearly double the true values if animals are absent at night, or infinitely low if occupance is concentrated then, darkness lasting for roughly $45 \%$ of total yearly time. These extremes were not found, but the Scottish Blackface sheep had a marked diurnal pattern in movement (Welch, 1981). At four of the moorland sites greater numbers of sheep and cattle were present in the $3^{1 / 2}$-hr periods after dawn and before dark, and the animals often bedded down where they fed at dusk During darkness they usually moved little, so occupance was probably similar to that in the 7-hr dawn-dusk period. If so, estimated density would be at most $29 \%$ too low, when animals were absent in the mid-day period. Since some occupance occurred at this time, the present errors are probably quite small.

In lagomorphs droppings are mainly deposited outside a mid-day period when soft pellets are produced and reingested; this lasts for about $8 \mathrm{hr}$ in rabbits (Myers, 1955), and $7 \mathrm{hr}$ in mountain hares (Flux, 1970), so diurnal variation in distribution can much influence dung measurements. The rather high rate of dung deposition at Part I (Table 5) could be due 
to greater use at night when hares do most feeding, but the 30 positive counts afforded no evidence of increased occupance near dawn or dusk.

At the grass pasture the amount of cattle dung deposited differed markediy between spring and autumn, although defecation rate was fairly constant (Table 6). The cow-pats were smaller in spring, and much

Table 6

Estimates of defecation rates and volumes of dung deposited per animal-hour by cattle on a census area within a grass pasture.

\begin{tabular}{|c|c|c|c|}
\hline $\begin{array}{l}\text { Period of } \\
\text { measurement }\end{array}$ & $\begin{array}{c}\text { Estimated } \\
\text { usage } \\
\text { (cattle-hours) }\end{array}$ & $\begin{array}{c}\text { Calculated No. } \\
\text { of defecations } \\
\text { per animal- } \\
\text { day }\end{array}$ & $\begin{array}{l}\text { Calculated rate } \\
\text { of dung } \\
\text { deposition } 1 \\
\text { (ml/animal-hour) }\end{array}$ \\
\hline 10 Маy-16 May & 21.9 & 20.8 & 450 \\
\hline 27 Мay-29 May & 64.2 & 16.4 & 474 \\
\hline 2 June- 8 June & 64.9 & 19.6 & 392 \\
\hline Spring (190 hrs observations) & 151.0 & 18.4 & 435 \\
\hline 30 Aug-4 Sept & 50.4 & 21.9 & 794 \\
\hline 6 Oct-9 Oct & 18.6 & 21.9 & 1052 \\
\hline 19 Oct-23 Oct & 4.3 & 27.7 & 1010 \\
\hline Autumn (140 hrs observations) & 73.4 & 22.2 & 876 \\
\hline Average of period means & & 21.4 & 695 \\
\hline Overali total & 224.4 & 19.7 & 587 \\
\hline
\end{tabular}

${ }^{1}$ Adjusted to a common live-weight (W) of $300 \mathrm{~kg}$ assuming dung output is proportional to $W^{\cdot 75}$.

more liquid. The pasture was in good condition, and high digestibility of the spring forage seems to have reduced both the dry-matter content and volume of dung egested. The year-round average for the voiume of dung deposited per animal-hour was probably quite close to the autumn mean, thus being comparable with the estimate in Table 4, allowing for somewhat greater output on less-digestible forage.

These data indicate a weakness in the dung-volume method, although on rough grazings the seasonal variation in dung output is probably 'ess. Defecation rate might seem a better measure of occupance being more constant, but it was often difficult to distinguish individual defecations even with daily visits because cattle frequently move when dunging. Indeed in $72 \%$ of the spring defecations, and $43 \%$ of the autumn, the deposits were spatially separate in trails; possibly the failure to identify multiple deposits explains why the calculated defecation rates are so much greater than the commonly accepted value of 12/day (Marsh \& Campling, 1970), obtained by watching individual animals. MacLusky (1960), by grouping adjacent lots of cattle dung, converted an observation of 15.5 deposits/day into an estimated 11.6 defecations/day.

Few similar tests have reported. Pellet-group counting has sometimes 
been found inaccurate (Batcheler, 1975 ; Dzięciołowski, 1974 ; Leckenby, 1968; Neff, 1968), but most of the errors do not affect dung weight or volume. The observation that large amounts of sheep dung are often deposited in a small proportion of the total range (Crofton, 1949; Hilder, 1966) reflects only aggregation, e.g., in resting areas, there being no evidence of selectivity in defecation. De Bie (1976), studying sheep grazing 11 ha of mixed grassland and heath for $4^{1 / 2}$ months, accounted for the occupance of twenty component parts belonging to seven vegetation types, the calculated rate of deposition in each being reasonably constant. Rawes \& Welch (1969) also obtained a satisfactory relationship between volumes of dung deposited and numbers of Swaledale sheep counted twice or five times a week on census areas of $0.2-2.0$ ha. With rabbits in New Zealand, Gibb et al. (1969) found pellet density to be related to the numbers present in an enclosure over the previous three months, despite pellet age and decay rate being unknown.

\section{Observation on Variability in Dung Output}

Some diurnal variation in the quantities defecated was evident, less dung being collected at night in sheep, and in the morning in deer, except on ad lib diets (Table 7). Output from 8.00 to $16.00 \mathrm{hrs}$ was largest when the night-time output was low. The inconsistency between animals and diets may be due to differences in the rate of passage of food.

The frequency of defecation was rather lower at night, more often no dung being produced in the 2-hr sampling periods, perhaps because disturbance was less, but only for deer on ad lib diet were the differences significant. Although much more dung was collected in 2-hr periods following nil than positive occurrences, on all diets in both animals, the 8-hr periods with less frequent defecation had lower output. On ad lib diets only rarely was no dung egested in the $2-\mathrm{hr}$ periods, which is consistent with a daily defecation rate somewhat greater than 12 in both species. On lower diets defecation was less frequent, but these intake rates will seldom occur under field conditions. In three trials only one food was given, but defecation pattern was unaffected.

It has long been thought that cattle and sheep deposit more dung at night than in daytime (Stapledon \& Davies, 1941; Sears, 1953; Frame, 1971), but recent studies on cattle e.g., those cited by Marsh \& Campling (1970) are equivocal ; if variation exists it is only slight. Pattern in defecation has also been found in sheep in digestibility trials (Blaxter et al., 1956; Hogan \& Phillipson, 1960; Minson \& Cowper, 1966), but output peaked at times of feeding and no differences were apparent 
between day and night. Blaxter et al. got greatest pattern in output when retention time of food was least, but the extremes differed from the overall mean by at most $15 \%$. Under field conditions with foods of varying digestibility, less variation could be expected. For red grouse also, Savory (1974) found no difference in dung-deposition rate between day and night.

Table 7

Variation in amount ( $\mathrm{g}$ fresh dung per $8 \mathrm{hrs}$ ) and frequency ( $\% 2-\mathrm{hr}$ periods in which dung is egested) of defecation according to time of day. The duration of measurements in animal-days is bracketed.

\begin{tabular}{|c|c|c|c|c|c|c|c|c|}
\hline & & Period o & day (hr & S.M.T.) & & & & \\
\hline & & $\begin{array}{l}0400- \\
1200\end{array}$ & $\begin{array}{l}1200- \\
2000\end{array}$ & $\begin{array}{c}2000- \\
0400\end{array}$ & Sign & & $\begin{array}{r}\text { Who } \\
\mathrm{r}\end{array}$ & rial \\
\hline & & & $\mathrm{SH}$ & EEP & & & & \\
\hline Low diet & $g$ & $\begin{array}{l}95 \\
47\end{array}$ & $\begin{array}{l}96 \\
37\end{array}$ & $\begin{array}{l}82 \\
37\end{array}$ & (12) & & 92 & (44) \\
\hline Moderate diet & $\mathrm{g}$ & $\begin{array}{r}41 \\
179\end{array}$ & 185 & 123 & (12) & *** & 159 & (42) \\
\hline & $\%$ & 66 & 75 & 59 & & & & \\
\hline High diet & $\underset{0 \%}{g}$ & $\begin{array}{r}254 \\
79\end{array}$ & $\begin{array}{r}251 \\
81\end{array}$ & $\begin{array}{r}216 \\
71\end{array}$ & (18) & ** & 227 & (50) \\
\hline Ad Lib & g & 481 & 459 & 489 & (24) & & 476 & (62) \\
\hline & $\%$ & 97 & 87 & 92 & & & & \\
\hline All diets & $\stackrel{g}{g}$ & $\begin{array}{r}294 \\
77\end{array}$ & $\begin{array}{r}287 \\
74\end{array}$ & $\begin{array}{r}274 \\
70\end{array}$ & & & 281 & \\
\hline & & & RED & DEER & & & & \\
\hline Low diet & $\underset{\%}{g}$ & $\begin{array}{r}201 \\
66\end{array}$ & $\begin{array}{r}231 \\
69\end{array}$ & $\begin{array}{r}233 \\
66\end{array}$ & (12) & & 199 & (43) \\
\hline Moderate diet & $\begin{array}{l}\mathrm{g} \\
0 \%\end{array}$ & $\begin{array}{r}279 \\
81\end{array}$ & $\begin{array}{r}338 \\
87\end{array}$ & $\begin{array}{r}272 \\
75\end{array}$ & (12) & ** & 287 & $(42)$ \\
\hline High diet & $\begin{array}{l}\mathrm{g} \\
0 \%\end{array}$ & $\begin{array}{r}340 \\
82\end{array}$ & $\begin{array}{r}404 \\
84\end{array}$ & $\begin{array}{r}439 \\
91\end{array}$ & (16) & & 404 & (46) \\
\hline$A d L i b$ & $\underset{\%}{g}$ & $\begin{array}{r}797 \\
98\end{array}$ & $\begin{array}{r}661 \\
83\end{array}$ & $\begin{array}{r}689 \\
87\end{array}$ & $(24)$ & $\begin{array}{r}* * \\
* * *\end{array}$ & 719 & (68) \\
\hline All diets & g & $\begin{array}{r}470 \\
85\end{array}$ & $\begin{array}{r}455 \\
82\end{array}$ & $\begin{array}{r}462 \\
82\end{array}$ & & & 460 & \\
\hline
\end{tabular}

Significant variation in defecation between $8-\mathrm{hr}$ periods of the day, as tested by one-way analysis of variance, is shown ${ }^{* *}(P<0.05>0.01)$, ${ }^{* * *}(P<0.01)$. The data used were 3 -day averages from individual trials.

Variation in intake and food digestibility between areas and between seasons is potentially more important in affecting defecation. The digestibility to sheep of plants occurring in pastures and rough grazings in Britain ranges between 35 and $80 \%$ (Black, 1967), and the diet consumed by a flock of hill sheep over several years varied from 48 to $75 \%$ in digestibility (Eadie, 1967), an increase that could halve dung dry-matter output if intake stayed constant. Commonly intake increases when food is more digestible especially in the lower range of digestibility values (Ulyatt, 1973), and the volume of output is also stabilised by the water 
content particularly in cattle. Estimating the likely magnitude of the controlling factors suggests that volume outputs in three-monthly periods could be $20 \%$ above or below overall averages.

\section{Calculation of Conversion Factors relating Dung Volume to Animal Occupance}

The volume of dung deposited per day can be calculated in several different ways. None gives completely acceptable values either because data are insufficient or assumptions have not been properly tested, yet taken together the estimates yield reasonably reliable mean rates of dung deposition. Available information for the present herbivores is assembled in Table 8 ; the methods of estimation and the data involved are now considered in turn. Allowance is made where possible for animal live weight, weights have been converted to volumes using the data in Table 1, and fresh dung was assumed to have a density of 1 .

Direct measurement of dung output by animals in cages or fitted with faecal harnesses is the most obvious way of obtaining conversion factors. Many workers have used such animals, but few estimates of output have been published because there have usually been other objectives e.g. determination of defecation rate in lagomorphs and organic-matter output in ruminants. The feeding of easily-digested artificia! foods, and the lower energy requirements when movement is restricted in small cages may reduce output e.g. by hares in the feeding trial of Flux (1970). Field et al. (1974) obtained their data from different classes of sheep at different times of year; this is a valuable estimate because numbers ranged from 11 to 34 .

Measuring deposition by following individual animals is very timeconsuming, hence the estimates given were obtained from few animals observed for only short periods. There is also the problem of darkness; de Bie (1976) made observations very largely, and Peterson et al. (1956) only, ir daylight, and it was assumed that diurnal pattern was insignificant. Measuring deposition over a period by known numbers of animals is also time-consuming, because either plots have to be continuously watched to record animal presence (Rawes \& Welch, 1969), or much dung has to be collected if enclosures are not so small as to seriously modify behaviour. Again darkness is a problem, but individual variation in dunging is less likely to bias the estimates.

The fourth method of determining conversion factors involves estimating occupance by counting at sites where dung deposition is measured. Most of the data comes from Tables 4, 5 and 6 . The reliability of these estimates and those of Brasher \& Perkins (1973) for Welsh 
Table 8

Estimates by different methods of rates of dung deposition ( $\mathrm{ml} / \mathrm{hr}$ ).

\begin{tabular}{|c|c|c|c|c|c|c|}
\hline & Sheep & Red Deer & Cattle & $\begin{array}{c}\text { Mountain } \\
\text { Hare } 1\end{array}$ & Rabbit & $\begin{array}{l}\text { Red } \\
\text { Grouse }\end{array}$ \\
\hline $\begin{array}{l}\text { (Mean liveweight of } \\
\text { average animals }-\mathrm{kg} \text { ) } \\
\text { Measuring deposition }\end{array}$ & (35) & (65) & $(300)$ & (1.8) & (1.2) & $(0.5)$ \\
\hline by captive animals & $65^{1}$ & & & $13^{2 *}$ & & 64 \\
\hline $\begin{array}{l}\text { Measuring deposition } \\
\text { by individual animals } \\
\text { under continuous } \\
\text { observation }\end{array}$ & $56^{\mathbf{5}}$ & & $1057^{6 *}$ & & & \\
\hline $\begin{array}{l}\text { Measuring deposition } \\
\text { by known numbers of } \\
\text { animals on known areas }\end{array}$ & $57^{7}$ & & $755^{8 *}$ & & & \\
\hline $\begin{array}{l}\text { Measuring deposition } \\
\text { by estimated nos. } \\
\text { of animals on known } \\
\text { areas }\end{array}$ & $\begin{array}{l}57^{9} \\
59^{10 *} \\
57^{11}\end{array}$ & $83^{11}$ & $\begin{array}{r}1254^{11} \\
876^{12}\end{array}$ & $40^{13}$ & $24^{18}$ & $6^{11}$ \\
\hline $\begin{array}{l}\text { Calculating from } \\
\text { estimates of defecation } \\
\text { rate and size }\end{array}$ & $55^{14}$ & $\begin{array}{l}86^{15} \\
93^{16}\end{array}$ & $\begin{array}{r}815^{17 *} \\
1150^{18 *}\end{array}$ & $12^{10}$ & $7^{20}$ & \\
\hline $\begin{array}{l}\text { Calculating from } \\
\text { estimates of intake } \\
\text { and digestibility }\end{array}$ & $53-66^{12}$ & $105-128^{12}$ & $672-952^{21}$ & $11^{22 *}$ & & $6=8$ \\
\hline Other reported values & $\begin{array}{c}39^{24} \\
59^{25} \\
125^{26 *} \\
45^{27}\end{array}$ & & $\begin{array}{l}1192^{26} \\
1262^{27} \\
1250^{28 *} \\
1192^{29 *}\end{array}$ & & & \\
\hline $\begin{array}{l}\text { Present best estimate } \\
\text { (rounded-off) }\end{array}$ & 60 & 110 & 800 & 15 & 10 & 6 \\
\hline
\end{tabular}

${ }^{1}$ Field et al. (1974): Scottish Blackfaces with harnesses grazing hill pasture gave $11 \mathrm{~g}$ dry matter/day/kg body wt**.

${ }^{2}$ Flux (1970): 2 hares in a 10-day trial gave $64 \mathrm{~g}$ fresh $\mathrm{wt} / \mathrm{day}^{+}$

3 Seiskari (1963): 2 young weighing c. $700 \mathrm{~g}$ gave $35 \mathrm{~g}$ dry $w$ t/day on natural vegetation**.

4 Moss \& Parkinson (1972): $45 \mathrm{~g}$ dry wt/day, body wt assumed $0.6 \mathrm{~kg}$ **.

5 de Bie (1976): 4 Scheelenbakers observed for $52 \mathrm{hrs}$.

6 Peterson et al. (1956): 2 cows for 5 days gave $56 \mathrm{lb}$ fresh wt/day ${ }^{+}$.

7 Rawes \& Welch (1969): $50 \mathrm{ml} / \mathrm{sheep}-\mathrm{hr}$ for Swaledales, average wt $29 \mathrm{~kg}$.

8 Goodall (1951): Jersey cows gave $40 \mathrm{lb}$ fresh wt/day for 36 cow-days ${ }^{+}$.

- Rawes \& Welch (1969): $50 \mathrm{ml} / \mathrm{sheep}-\mathrm{hr}$ for Swaledales, average wt $29 \mathrm{~kg}$.

10 Brasher \& Perkins (1973): Welsh Mountain sheep gave $380 \mathrm{~g}$ dry wt/day**.

11 Table 4 \& 5

${ }_{12}$ Table 6 , assuming the autumn rate equals the year-round average.

${ }_{13}$ Table 5 , partitioning the estimate of $35 \mathrm{ml}$ according to numbers seen and biomass.

14 Assuming 16 defecations/day (ex Longhurst 1954, De Bie 1976) and using means from Table 2 \& 3 .

15 Assuming 12 defecations/day (Neff 1968) and using means from Table 2 \& 3.

16 Riney (1957): 10 defecations/day, mean wt $58.3 \mathrm{~g}$ for 32 deer-days and 10 defecations despectively; if the weight is for fresh dung, rate would be much less.

${ }^{17}$ Goodall (1951): 12 defecations/day, mean wt $3.6 \mathrm{lb}$ fresh ${ }^{+}$; perhaps from same data as 8 .

${ }_{18}$ Assuming 12 defecations/day (Marsh \& Campling 1970), using $2300 \mathrm{~g}$ fresh wt/defecation (Waite et al., 1951) ${ }^{+}$ 
19 Assuming 320 pellets/day (ex Flux, 1967 \& 1970; Lampio, 1952) and using mean from Table 2 .

20 Assuming 400 pellets/day (Lockley, 1962) and using mean pellet size $0.4 \mathrm{ml}$ (Table 2).

21 Intake $0.8-1.0,1.4-1.7,6.0-8.5 \mathrm{~kg}$ dry wt/day, digestibility $57,56,57 \%$ for sheep, red deer and cattle respectively, from values given by Church (1972), Eadie (1967), Engels et al. (1974), Maloiy et al. (1968) and others for normal growth of non-lactating animals**.

${ }_{22}$ Flux (1970) estimated intake from passage rates and trends in stomach wt of shot animals at $280 \mathrm{~g}$ fresh wt/day; $35 \%$ digestibility and $35 \%$ dry-matter content are assumed**.

${ }_{23}$ Savory (1974) estimated intake from peck rates and particle size at $60 \mathrm{~g}$ dry wt/day for birds of $6.3 \mathrm{~kg}$ body wt; $30 \%$ digestibility is assumed (Moss \& Parkinson, 1972)**. By a difference method Miller \& Watson (1978) found slightly larger intake with caged birds on a heather moor.

${ }_{24}$ Ziolecka (1969): $0.28 \mathrm{~kg}$ dry wt/day for $40-\mathrm{kg}$ sheep**.

25 Alkiewicz \& Sliwa (1969): $2 \mathrm{~kg}$ fresh wt/day for $55-\mathrm{kg}$ sheep ${ }^{+}$.

26 Spedding (1975): 42 litres/day for $500-\mathrm{kg}$ cattle; sheep wt could be as great as $70 \mathrm{~kg}$.

27 Spedding (1971): 1.8 and $34 \mathrm{~kg}$ fresh wt/day respectively for $70-\mathrm{kg}$ sheep and $350-\mathrm{kg}$ cattle**.

28 Gisiger (1950): German cows.

20 Marsh \& Campling (1970): from means of others for DOM output, dung ash and dry-matter content.

* Animal size unknown; other values were converted when appropriate to the mean species wt assuming dung output is proportional to $W .75$.

** Converted to volume using the values for $D W: V$ in Table 1

+ Converted to volume assuming dung density $=1.0$.

Mountain sheep, is reduced by diurnal patterns in behaviour; this applies much less to the values for Swaledale sheep (Rawes \& Welch, 1969).

Fifthly daily output of dung can be calculated from defecation rate and volume. Only two estimates based on the factors measured together are available (Goodall, 1951; Riney, 1957), but too few animals were observed for too short a period to give reliable data. The other values come from the estimates of pellet size and number per group in Tables 2 ard 3, and the mean defecation rates previously reported. These latter were obtained by equivalent means to the four methods just considered, and the same difficulties and sources of error apply; also there are problems such as distinguishing individual pellet groups. However, so many estimates for ruminants are available that the values used are probably quite accurate. Defecation rates and pellet size in lagomorphs are much less certain.

Lastly, conversion factors can be estimated from intake rates and food digestibilities. Although the nutritional requirements of cattle and sheep are well known (Church, 1972), and in agreement with observed intake on good grazings, there is little information on actual rates of intake and digestibility on rough grazings; for lagomorphs hardly any data. So the calculated values are only a check on the other estimates of dung output.

Most likely values for the volume of dung produced per hour by each 
herbivore on rough grazings of the present type have been decided bearing in mind the accuracy of all estimates (Table 8); due to shortage of data the value for deer was extrapolated from sheep. Cattle produce about double the volume output of sheep per $\mathrm{kg}$ liveweight. This could be expected, dung dry-matter content being $44 \%$ that of sheep (Table 1). Grouse and lagomorphs also have high rates of output per kg liveweight, due to faster throughput and lower digestion of forage, besides differences in metabolic rate.

\section{GENERAL DISCUSSION}

The results show beyond doubt that an estimate of occupance of ground by herbivores can be obtained from the volume of dung they deposit: amounts actually deposited by estimated numbers agreed with expected rates calculated from other data. But the precision of the relationships could not be checked because occupance could not be determined accurately. Some sources of error were however demonstrated, particularly variations in volume caused by varying digestibility and intake rates. The scale of these errors has to be compared with those inherent in other methods of assessing occupance, and the feasibility of all methods must be considered.

In some situations methods using animal sign are clearly inappropriate or ever. impossible (Julander et al., 1963; Riney, 1957; Neff, 1968). Sampling may be impeded by microtopography or vegetation eg. in dense thickets or fragile communities; the sign may be modified or lost e.g. on sea-shores and other areas regularly flooded, on steep slopes, on bare ground subject to strong winds, and where dung is eaten or decomposes; the sign may not accumulate in proportion to presence e.g. when created only during certain activities or when herbivores dung in special areas. Sometimes such impediments act only intermittently or to small extents, and it is a matter for judgement whether the error is tolerable. Thus very strong winds can move dung in almost all types of vegetation, but occur so rarely that in most vegetation estimates made by measuring at three-weekly intervals will be affected by less than $5 \%$. Similarly the effect of dunging on special sites depends on the extent of their use relative to other ground; thus defecation by horses may be so selective (Taylor, 1954) that occupance cannot be measured, but rabbits spent so little time on dung-hills, with little variation in the rate of pellet deposition (Mykytowycz \& Gambale, 1969), that little error can result.

Possible errors of $20 \%$ in dung volumes for three-monthly periods due 
to variations in herbage intake and digestibility, and to weather factors, have been suggested. These errors will occur independently, and their magnitude will fall as period length increases, but allowing also for diurnal variation in defecation, technical imprecision and other possible errors previously mentioned, the year-round estimates of occupance could be as much as $25 \%$ above or below true values.

Estimates of occupance based on dung dry weight or on pellet number or pellet-group number will be unaffected by weather but may well be much influenced by seasonal variation in herbage quality. In lagomorphs pellet size may be more affected than defecation rate (Arnold \& Reynolds, 1943), but in ruminants defecation rates on different diets can diverge from mean values by as much as $25 \%$ (Neff, 1968). Also juveniles have aberrant rates especially when suckling which do not reflect biomass unlike the weight or volume of dung. In both pellet methods decisions on what dung is fresh can cause serious error (Taylor \& Williams, 1956; Cochran \& Stains, 1961; and van Etten \& Bennett, 1965) unless plots are cleared at regular counts. In pellet-group methods much inaccuracy can occur in deciding the number of groups both when the pellets are inextricably mixed after intensive grazing or strewn out on deposition or subsequently by rain and disturbance, and straddle plot boundaries. Batcheler (1975) ascribed a five-fold decrease in the apparent number of groups as plot diameter was increased from $71 \mathrm{cr}$ : to $7 \mathrm{~m}$ to this cause, but other workers finding similar reductions, e.g. Smith (1968), thought the observers had missed groups.

Direct counting has been shown to be unreliable as a measure of occupance, especially when animals group together and show diurnal patterns of movement. Besides the sampling in space, as in dung methods, there is extreme sampling within time. Even if sufficient counts are made to integrate daytime variation, the uncertainties of night-time usage remain. Other indirect methods using sign, such as track counts or plant utilisation, depend on voluntary activities, hence are likely to be imprecise.

To sum up, the dung-volume method in many circumstances gives a reasonably accurate measure of occupance for a moderate input of labour. Rather more accurate results can be obtained by the determination of dung dry-weights, but require greater input of labour. Direct counting, pellet counts and pellet-group counts are considered less accurate.

Finally it must be remarked that much more work is still needed to produce good methods of measuring occupance, and to define the circumstances in which they can be applied. Studies on the rates, quantities and characteristics of defecation in relation to intake and digestibility are especially required. 
Acknowledgements: I wish to thank the landowners and tenant farmers who allowed me to visit the study sites, and the assistants who helped with the counts and dung measurements, particularly Carolyn Cummins, Eddie Kemp and Tim Parish. I am indebted to Dr. Robin Kay for permission to use his data on dung output. Mr A. J. P. Gore, Prof. F. T. Last and Dr. R. Moss have commented on the drafts.

\section{REFERENCES}

1. Alkiewicz W. \& Sliwa Z., 1958: Poradnik chowu owiec. PWRiL, 1-213, Warszawa.

2. Arnold J. F. \& Reynolds H. G., 1943: Droppings of Arizona and Antelope Jack rabbits and the "pellet census". J. Wildl. Mgmt., 7: 322-327.

3. Batcheler C. L., 1975: Development of a distance method for deer census from pellet groups. J. Wildl. Mgmt., 39: 641-652.

4. Bie S. de 1976: Onderzoek naar beweiding als natuurtechnische beheermaatregel op het "Westerholt". Int. Rep. Rijskinst. voor Natuurbeheer, $84 \mathrm{pp}$.

5. Black J. S., 1967: The digestibility of indigenous hill pasture species. Hill Farming Research Organisation, Report No 4, 33-37.

6. Blaxter K. L., Graham N. McC. \& Wainman F. W., 1956: Some observations on the digestibility of food by sheep, and on related problems. Br. J. Nutr., 10: $69-91$.

7. Blaxter K. L. \& Wood W. A., 1953: Some observations on the biochemical and physiological events associated with diarrhoea in calves. Vet. Rec., 65: 889-892.

8. Brasher S. \& Perkins D. F., 1973: The grazing intensity and productivity of sheep in the grassland ecosystem. Part II. Br. Ecol. Soc. Bull., 4: (3) 17.

9. Church D. C., 1972: Digestive physiology and nutrition of ruminants. Vol. 2 Nutrition. D. C. Church, Corvallis, Oregon 801 pp.

10. Cochran G. A. \& Stains H. J., 1961: Deposition and decomposition of fecal pellets by cottontails. J. Wildl. Mgmt., 25: 432-435.

11. Crofton H. D., 1958: Nematode parasite populations in sheep in lowland farms. VI Sheep behaviour and nematode infections. Parasitology, 48: 251-260.

12. Dzięciołowski R. M., 1974: The use of pellet-group counts to census red deer. Proc. Iint. Congr. Game Biol., 11: 559-563.

13. Eadie J., 1967: The nutrition of grazing hill sheep; utilisation of hill pastures. Hill Farming Research Organisation, Report No 4: 38-45.

14. Engels E. A. N., Malan A. \& Baard M. A., 1974: The volutary feed intake of dry and lactating cows on natural pasture. S. Afr. J. Anim. Sci., 4: 113-116.

15. Etten R. C. van \& Bennett C. L., 1965: Some sources of error in using pelletgroup counts for censusing deer. J. Wildl., Mgmt., 29: 723-729.

16. Field A. C., Sykes A. R. \& Gunn R. G., 1974: Effects of age and state of incisor dentition on faecal output of dry matter and on faecal and urinary output of nitrogen and minerals, of sheep grazing hill pastures. J. agric. Sci., Camb., 83: 151-160.

17. Flux J. E. C. 1967: Hare numbers and diet in an alpine basin in New Zealand. Proc. N.Z. ecol. Soc., 14: 27-33.

18. Flux J. E. C., 1970: Life history of the Mountain hare (Lepus timidus scoticus) in north-east Scotland, J. Zool., Lond., 161: 75-123.

19. Frame J., 1971: Fundamentals of grassland management. Part 10: The grazing animal. Scott. Agric., 50: 28-44. 
20. Gibb J. A., Ward G. D. \& Warr C. P., 1969: An experiment in the control of a sparse population of wild rabbits (Oryctolagus c. cuniculus L.) in New Zealand. N.Z. J. Sci., 12: 509-534.

21. Gill J., 1961: [The rate of passage of foodstuffs through the alimentary canal and some physical characteristics of the faeces of red deer (Cervus elaphus L.)] Proc. Int. Congr. Game Biol., 5: 161-174.

22. Gisiger L., 1950: Organic manuring of grassland. J. Br. Grassld. Soc., 5: 63-79.

23. Goodall V. C., 1951: The day and night grazing system. Proc. N.Z. Grassld Ass., 13: $86-94$

24. Greenham P. M., 1972: The effects of the variability of cattle dung on the multiplication of the bushfly (Musca vetustissima Walk.). J. Anim. Ecol., 41: $153-165$.

25. Hansen R. M., 1972: Estimation of herbage intake from jackrabbit faeces. J. Range Mgmt., 25: 468-471.

26. Hilder E. J., 1966: Distribution of excreta by sheep at pasture. Proc. Int. Grassld Congr., 10: 977-981.

27. Hogan J. P. \& Phillipson A. T., 1960: The rate of flow of digesta and their removal along the digestive tract of the sheep. Br. J. Nutr., 14: 147-155.

28. Julander O., Ferguson R. B. \& Dealy J. E., 1963: Measure of animal range use by signs. In: U.S. Forest Service Range Research Methods. U.S. Dept. Agric. Misc. Publ. 940: pp 102-108.

29. Lampio T., 1952: An experiment in the control of disease in the snow hare. Riistat. Julk., 8: 139-142.

30. Leckenby D. A., 1968: Influences of plant communities on wintering mule deer. Proc. a. Conf. west. Ass. St. Game Fish Commnrs, 49: 201-208.

31. Lockley R. M., 1962: Production of faecal pellets in the wild rabbit. Nature, Lond., 194: 988-989.

32. Longhurst W. M., 1954: The fecal pellet group deposition rate of domestic sheep. J. Wildl. Mgmt., 18: 418-419.

33. MacLusky D. S., 1960: Some estimates of the areas of pasture fouled by the excreta of dairy cows. J. Br. Grassld Soc., 15: 181-188.

34. Maloiy G. M. O., Kay R. N. B. \& Goodall E. D., 1968: Studies on the physiology of digestion and metabolism of the red deer. Symp. zool. Soc. Lond., 21: 101-108.

35. Marsh R. \& Campling R. C., 1970: Fouling of pastures by dung. Herb. Abstr., 40: $123-130$.

36. Miller G. R. \& Watson A., 1978: Heather productivity and its relevance to the regulation of red grouse populations. [In: "Production Ecology of British Moors and Montane Grasslands", Eds. O. W. Heal \& D. F. Perkins] Springer: 277-285, Berlin.

37. Minson D. J. \& Cowper J. L., 1966: Diurnal variations in the excretion of faeces and urine by sheep fed once daily or at hourly intervals. Br. J. Nutr., 20: $757-764$.

38. Moss R. M. \& Parkinson J. A., 1972: The digestion of heather (Calluna vulgaris) by red grouse (Lagopus lagopus scoticus). Br. J, Nutr., 27: 285-298.

39. Myers K., 1955: Coprophagy in the European rabbit (Oryctolagus cuniculus) in Australia. Aust. J. Zool., 3: 336-345.

40. Mykytowycz R. \& Gambale S., 1969: The distribution of dung-hills and the behaviour of free-living wild rabbits, Oryctolagus cuniculus (L.) on them. Forma et Functio, 1: 333-349. 
41. Neff D. J., 1968: The pellet-group count technique for big game trend, census, and distribution: a review. J. Wildl. Mgmt., 32: 597-614.

42. Olechowicz E., 1974: Analysis of a sheep pasture ecosystem in the Pieniny Mountains (The Carpathians). X. Sheep dung and the fauna colonising it. Ekol. pol., 22: 589-616.

43. Peterson R. G., Lucas H. L. \& Woodhouse W. W., 1956: The distribution of excreta by freely grazing cattle and its effect on pasture fertility. I. Excreta; Distribution. Agron. J., 48: 440-444.

44. Rawes M. \& Welch D., 1966: Further studies on sheep grazing in the northern Pennines. J. Br. Grassld Soc., 21: 56-61.

45. Rawes M. \& Welch D., 1969: Upland productivity of vegetation and sheep a: Moor House National Nature Reserve, Westmorland, England. Oikos, Suppl.. 11: $1-72$.

46. Riney T., 1957: The use of faeces counts in studies of several free-ranging mammals in New Zealand. N.Z. J1. Sci. Technol. Sect. B, 38: 507-532.

47. Rook J. A. F. \& Balch C. C., 1959: The physiological significance of the fluid consistency of faeces from cattle spring pasture. Proc. Nutr. Soc., 18: xxxv.

48. Savory C. J., 1974: The feeding ecology of red grouse in N. E. Scotland. Ph. D. thesis, University of Aberdeen.

49. Sears P. D., 1953: Pasture growth and soil fertility. V. The effects of nitrogenous fertilisers, and of "day" and "night" grazing. N.Z. J1. Sci. Technol. Sect. A, 35: $68-77$.

50. Seiskari P., 1963: Jäniksen kesäravinnosta. Suom. Riista, 16: 46-55.

51. Smith R. H., 1968: A comparison of several sizes of circular plots for estimating deer pellet-group density. J. Wildl. Mgmt., 32: 585-591.

52. Spedding C. R. W., 1971: Grassland Ecology. Clarendon Press: 1-221. Oxford.

53. Spedding C. R. W., 1975: The Biology of Agricultural Ecosystems. Academic Press: $1-261$. London.

54. Stapledon R. G. \& Davies W., 1941: Ley farming. Penguin Books: 1-160. Harmondsworth.

55. Taylor E. L., 1954: Grazing behaviour and helminthic disease. Br. J. Anim. Behav., 2: $61-62$.

56. Taylor R. H. \& Williams R. M., 1956: The use of pellet counts for estimating density of populations of the wild rabbit, Oryctolagus cuniculus (L.) N.Z. J. Sci. Technol. Sect. B, 38: 236-256.

57. Ullyat M. J., 1973: The feeding value of herbage. [In: "Chemistry and Biochemistry of Herbage", Vol. 3, ed. G. W. Butler and R. W. Bailey]. Academic Press: $131-178$. London.

58. Waite R., MacDonald W. B. \& Holmes W., 1951: Studies in grazing management. III. The behaviour of dairy cows grazed under close-folding and rotational systems of management. J. agric. Sci., Camb., 41: 163-173.

59. Weeth H. J., Sawhney D. S. \& Lesperance A. L., 1967: Changes in body fluids, excreta and kidney function of cattle deprived of water. J. Anim. Sci., 26: $418-423$.

60. Welch D., 1971: Evaluating the dung method of measuring animal numbers. [In: "Range Ecology Research", 1st Progress Report]. The Nature Conservancy: 13-17. Edinburgh.

61. Welch D., 1981: Diurnal movements by Scottish Blackface sheep between improved grassland and a heather hill in north-east Scotland, J. Zool., Lond. 194: $267-271$. 
62. Wilson A. D., 1970: Water economy and food intake of sheep when watered intermittently. Aust. J. agric. Res., 21: 273-281.

63. Ziołecka A., 1971: Badania nad oznaczeniem strawności u przeżuwaczy. Roczn. Nauk rol., 127: 1-153.

Accepted, March 8, 1982.

David WELCH

\section{CHARAKTERYSTYKA KAEU I DEFEKACJI NIEKTORYCH SZKOCKICH ROSLINOZERCOW JAKO METODA DO OBLICZANIA ZAJMOWANEJ PRZESTRZENI}

\section{Streszczenie}

Badano wzajemne zależności suchej i świeżej masy oraz objętości odchodów bydła, owiec, jeleni (Cervus elaphus), zajęcy (Lepus spp.), królików (Oryctolagus cuniculus) i pardwy (Lagopus lagopus). Doświadczenia prowadzono w latach 1969-1977, w sezonach: maj-sierpień, wrzesień-grudzień i styczeń-kwiecień, przy trzech typach pogody: suszy, warunkach umiarkowanych i dużej wilgotnonści (deszcz przed lub w czasie pobierania prób). Próba była ważona w stanie świeżym, a następnie dzielona na pół, z czego jedną część suszono do stałego ciężaru a w drugiej określano objętość. Stosunek ciężaru suchej masy do objętości zależał zarówno od początkowej zawartości suchej masy, jak i od pogody (Tabele 1, 2, Ryc. 1). Odchody bydła były wyraźnie odmienne ze względu na dużą wilgotność. Mierzono objętość i ciężar poszczególnych peletek i ich liczbę wydalaną w czasie jednej defekacji (Tabela 3, Ryc. 2, 3). $\mathrm{Z}$ tych danych oraz $\mathrm{z}$ innych opublikowanych informacji obliczono, że odchody wydalane przez zwierzę średniej wielkości sięgają od $6 \mathrm{ml} /$ godz. u L. lagopus do $60 \mathrm{ml} /$ godz. u owcy i $800 \mathrm{ml} / \mathrm{godz}$. u bydła. (Tabela 8). Opisano test używany przy tej metodzie do oceny zajmowanego terytorium (Tabele $4,5,6,7$ ). 